\title{
11. Modelling the economic impact of the Sino-US trade dispute: A global perspective
}

\section{Deborah H.Y. Tan and Chen Chen ${ }^{1}$}

\section{Introduction}

The global economy works best when goods, services, people and ideas flow freely across administrative boundaries. The current prosperity we all enjoy is due, in no small part, to the benefits of international trade, which unlocks the positive benefits of national and regional comparative advantage. The position of our employer, BHP, on this point is clear.

Quoting directly from the six-monthly update that BHP publishes with its financial results:

While we stress that an increase in trade protection alone is not a recessionary level shock for the global economy, it is an exceedingly unhelpful starting point for the pursuit of broad based growth across regions, expenditure drivers and industries. That observation highlights the importance of continued advocacy for free trade and open markets by corporations, governments and civil society ... As the true economic costs of trade protection are progressively recognised by global consumers, we anticipate a popular mandate for a more open international trading environment will eventually emerge. (McKay 2019)

Exactly how large might those costs be and what can be done to mitigate them? That is what this chapter is about.

The current trade dispute between the United States and China stems from the Trump administration's long-held commitment to adopt a tougher stance against China to change what it regards as unfair trade practices. These practices are, in the administration's view, the reason for the US trade deficit with China. At a deeper level, the trade dispute can also be seen as a surface manifestation of the emerging superpower rivalry between the United States and China.

At the time of writing, talks between US and Chinese trade negotiators are under way and have gained traction in recent months. However, it is difficult to foresee the final outcome of the negotiations_-or, indeed, if there will be an end or whether this

1 The authors thank Warwick McKibbin, Larry Liu and Huw McKay for helpful suggestions on an earlier draft. 
issue is best seen as a continuum. Therefore, rather than presenting a single set of results, we have instead prepared a number of different scenarios, of varying intensity and duration, with varying counterpolicies in play, to capture the range of potential outcomes for the US, Chinese and global economies in the coming decade.

The scenarios have been simulated in the G-cubed multicountry model. A key reference for this chapter is McKibbin and Stoeckel (2017), who use the G-cubed model to simulate the effects of a range of multilateral trade war scenarios.

Our conclusion is that a trade war will, unsurprisingly, leave both the Chinese and the American people less prosperous than they would otherwise have been. Our definition of a full-blown Sino-US trade war will be costly for both countries and could reduce the size of both economies by 0.5 per cent, on average, over the next decade. While the impact on China is initially greater due to China's higher trade exposure, the cost to the United States increases over time. However, bystander countries stand to gain, at the margin, from the diversion of activity, with market share gains in both China and the United States for the likes of Germany, Japan and South Korea. It also appears to be strongly in China's interests to resolve the dispute through negotiation, while simultaneously pursuing a set of sensible countercyclical policies to cushion the Chinese domestic economy in the near to medium terms.

\section{The economic priorities of President Trump and President Xi}

President Donald Trump's major economic policy priorities have been to raise economic growth and create jobs by boosting investment. The levers used to do this have been lowering taxes (especially corporate taxes) and reducing regulation, while providing protection for US manufacturing by raising tariffs and renegotiating trade agreements. This platform has had mixed success, both legislatively and in terms of economic outcomes. The biggest legislative achievement to date-the Tax Cuts and Jobs Act, signed into law in December 2017-is arguably the most sweeping overhaul of the US tax system in more than 30 years. The tax package lifted growth above potential in 2018, and we estimate that it will continue to support investment, employment and wages above a counterfactual baseline for a half-decade or so. However, it is not self-financing and the Joint Committee on Taxation (2017) argues it will add an extra US\$1.1 trillion to the budget deficit over 10 years. The boost to domestic demand relative to that of the United States' trading partners also suggests that the US trade balance will worsen, running counter to the administration's efforts to reduce the nation's trade deficit.

On trade, President Trump has been able to use national security provisions in trade legislation to expedite measures, rather than seeking congressional approval. The basic line from the administration is that the large bilateral trade deficits the United States 
runs with its major partners are a sign that US exporters are being treated unfairly and that these partners should be buying more American exports. While China has not been alone in receiving US criticism on trade, ${ }^{2}$ China has arguably been the primary target. This has also extended beyond the bilateral relationship to shape US dealings with other nations. For instance, the new US-Mexico-Canada Agreement to replace the North American Free Trade Agreement includes a 'poison pill' provision allowing the United States to veto Canada's and Mexico's choices of other trading partners, and appears to be a clear effort to single out China.

While US policymaking has grown more nationalistic under the current administration, China is pursuing a broader long-run economic growth strategy and a more influential role regionally. The Chinese authorities continue to view economic growth as a key priority under the guidance of the thirteenth Five-Year Plan, which aims to double China's per capita income by 2020. At the same time, reforms have been promoted to a similar level of importance over the past five years as the maturing economy is confronted with various structural issues, mainly in the areas of industrial capacity, financial risk and the environment. Over the past five years, the Chinese Government has navigated a gradual growth slowdown alongside the implementation of various supply-side structural reforms. China has also pursued some unilateral trade reforms while negotiations with the United States have been proceeding, such as lower tariffs on cars, and it also passed a new foreign investment law at the most recent National People's Congress.

China's long-run goal to become a 'modernised and prosperous economy' by the mid-twenty-first century has also catalysed the pursuit of industrial policies that would drive its sizeable manufacturing sector (currently low to middle in terms of value added) up the value chain. 'Made in China 2025' is a well-known governmentbacked industrial policy focused on advancing China's manufacturing sector into a technological superpower and targeting key sectors such as information, communication and telecommunication, machinery and equipment and industrial materials. More broadly, China has been growing in influence in the Asia-Pacific over the past few years through establishing closer bilateral economic linkages. The Belt and Road Initiative, for instance, has become the backbone of the incumbent administration's foreign policies. The establishment of the Beijing-headquartered Asian Infrastructure Investment Bank highlighted China's commitment to play a serious role in terms of providing support for regional economic development. The sum of these moves presents a clear strategy to move China up the value chain while increasing China's role in international governance, particularly in the development financing sphere.

2 Elsewhere, President Trump has threatened to impose tariffs of up to 25 per cent on European car imports if he is unable to reach a deal with the bloc following findings from the US Commerce Department in February this year. Also, steel and aluminium tariffs have been global in nature, with only a few exemptions offered, and with countries in the Americas the most heavily impacted. 


\section{State of play on trade negotiations}

Concerns about Chinese trade practices, the treatment of foreign companies in China and questions about intellectual property rights protection are not new. According to the US Trade Representative (2019) and European Commission (European Chamber of Commerce 2018), many policymakers believe the Chinese Government has not met all its World Trade Organization (WTO) accession commitments. Claims include 'unfair' support for Chinese domestic companies, alleged forced technology transfers and denial of market access to international competitors. The American Chamber of Commerce in Shanghai (2017) notes significant barriers to entry in five key industries: financial services, information and communications technology, health care, agriculture and the automotive industry. Meltzer and Shenai (2019) and Hass and Balin (2019) from The Brookings Institution also observe that China's ambition to become a technology superpower has caused bipartisan consternation in the United States, centred on whether China would use industrial policy to provide, once again, 'unfair' support to domestic players. The rapid escalation in tensions in recent months has built on the foundations created by these perceptions.

From China's point of view, the US merchandise trade deficit reflects a number of structural factors. First, the current trade deficit is a reflection of the low level of US national savings, across the public and private sectors. The dollar's role as the global vehicle funding currency also necessitates the provision of US dollar liquidity through perpetual trade deficits_-also known as the Triffin dilemma. Finally, the comparative advantage of Chinese goods production and the redistribution and fragmentation of the global supply chain have led to major shifts in the country of origin of products American consumers buy, both from established brands and in terms of increases in indigenous Chinese firms' market share.

Tensions between the world's two largest economies have escalated rapidly following the US decision to impose tariffs on steel and aluminium imports in March 2018. Figure 11.1 provides a timeline of developments to date. So far, the United States has imposed duties on more than half of its imports of Chinese goods and China has retaliated with tariffs on more than 70 per cent of its imports of US goods. Between 30 November and 1 December 2018, a 'truce' agreement was reached between both countries at the G20 summit in Buenos Aires. As part of the temporary ceasefire, the United States agreed to postpone raising tariffs from 1 January 2019 and set a 90-day time frame for the two sides to make progress on key structural issues. On 24 February, President Trump decided to postpone the implementation of the more punitive tariffs that were due to come into effect on 1 March. At the time of writing, in early April 2019, talks are still under way between US and Chinese trade negotiators. While both governments have been keen to point out the highly productive nature of their talks, it remains to be seen whether substantive progress has truly been made. 


\section{March 2018}

US imposed $25 \%$ tariffs on steel and $10 \%$ tariffs on aluminum imports from China

China retaliated with tariffs on 128 US

products

\section{April 2018}

US proposed $25 \%$ tariffs on $\$ 50 \mathrm{~b}$ of Chinese goods relating to intellectual property theft and forced technology transfer

US proposed tariffs on an additional $\$ 100 \mathrm{~b}$ of imports as China did not 'remedy its misconduct'

\section{May 2018}

US senior officials travelled to Beijing to resume trade negotiations

\section{June 2018}

Despite several rounds of trade talks, the US announced tariffs on $\$ 50 \mathrm{~b}$ on Chinese imports. The tariffs would come into force in two tranches, $\$ 34 \mathrm{~b}$ from 6 July and the rest from 23 August

In response to Chinese retaliation, President Trump directed the US Trade Representative to identify an additional $\$ 200 \mathrm{~b}$ Chinese imports to be targeted with $10 \%$ tariffs

\section{July 2018}

US Trade Representative released list of Chinese imports worth $\$ 200 \mathrm{~b}$, President Trump threatened to increase tariffs from $10 \%$ to $25 \%$

\section{September 2018}

US imposed $10 \%$ tariffs on an additional $\$ 200 \mathrm{~b}$ Chinese goods

President Trump and President Xi spoke by phone and both parties expressed goodwill

\section{December 2018}

At the sidelines of the G20, the US and China agreed to hold back further tariff increases until 1 March 2019 and restart trade talks

\section{February 2019}

President Trump postponed the tariff increases due on 1 March given progress on trade talks

\section{April 2019}

US and Chinese officials conclude latest round of high-level trade talks with further consultation to follow on outstanding issues

Figure 11.1 Sino-US trade developments timeline

Source: BHP analysis.
China retaliated with 5-10\% tariffs on $\$ 60 \mathrm{~b}$ US imports

\section{November 2018}

China proposed $25 \%$ tariffs on $\$ 50 \mathrm{~b}$ imports from the US, including aircraft, soybeans and autos

At the Boao Forum, President Xi shared plans to increase China's imports demand, broaden market access to foreign capital, reduce tariffs in certain sectors and enhance intellectual property protection

China retaliated like for like

At the first China International Import Expo, Chinese authorities pledged to open its domestic market and improve business environment 
It is difficult to foresee the final outcome of the negotiations and what the United States might expect from China in exchange for either continued suspension of increased tariffs or removal of those tariffs that are in place. Other questions - such as those relating to industrial policy, market access and intellectual property-will also need to be resolved. In the unlikely event that negotiations fail completely, the United States has the upper hand in both the breadth and the volume of tariffs that it could impose, while China is unable to match like for like given its lower level of imports from the United States (Figure 11.2). Although China has insisted it does not wish to escalate the dispute, there are other policy tools the Chinese leadership could deploy to stabilise the economy, albeit with intertemporal trade-offs.

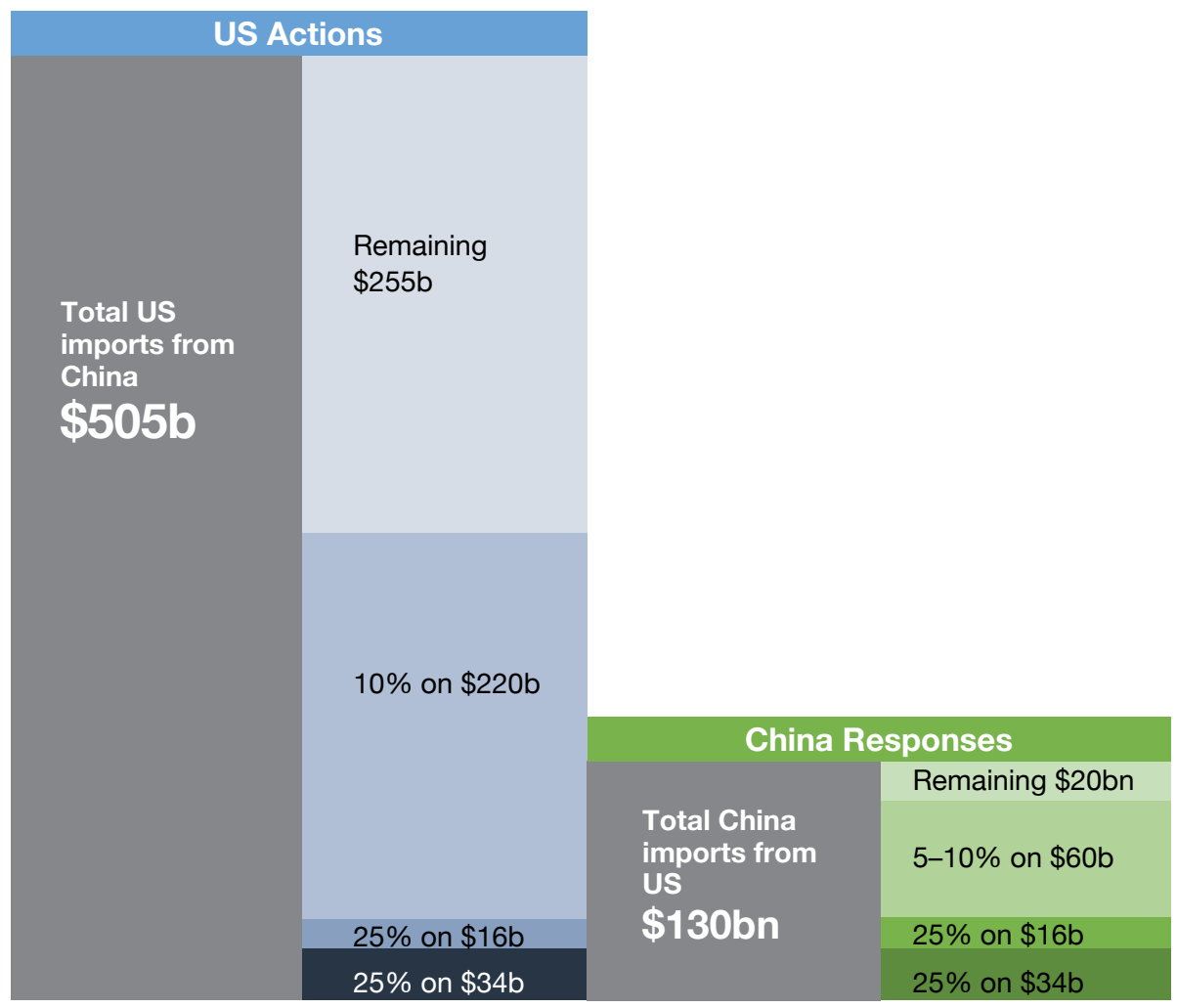

Figure 11.2 Trade policy actions from the United States and China Source: BHP analysis.

To assess the range of impacts of the conflict, we use a set of scenarios to capture three possible outcomes of the Sino-US trade dispute. At the time of writing, two scenarios have been overtaken by the pace of events. Taking the outcomes of the first set of scenarios into account, we then examine the impact of three Chinese policy countermeasures. Some of these countervailing measures have already been implemented, while others may yet be adopted. 


\section{The model}

The policy choices of the United States and China have a strong influence on their own domestic economies, each other's trade performance as well as the economic opportunities faced by their other trading partners. Protectionism increases operating costs for firms in import destination markets, reduces the purchasing power of consumers, reduces the rate of return on capital and leads to lower investment. Employment falls as businesses downsize and slack in the labour market depresses wages and spending. A full-blown Sino-US trade war will certainly be costly for both countries. Meanwhile, bystander countries such as Germany and Japan stand to gain from the diversion of activity. While Chinese stimulus policies could stabilise the economy in the near term, that would be at the expense of a higher fiscal deficit and the need for consolidation in the future.

To capture all of these influences and interactions, we have used the comprehensive dynamic global model originally developed by McKibbin and Wilcoxen (1999, 2013). The G-cubed model incorporates all of these interactions in a dynamic and global setting, with sectoral detail. The version used in this chapter is outlined in more detail in McKibbin and Stoeckel (2017). Specifically, the model version used here has six sectors (energy, mining, agriculture, manufacturing durables, manufacturing nondurables and services) plus a capital goods-producing sector and 17 countries/regions, as set out in Table 11.1. Each region's central bank is assumed to adjust short-term nominal interest rates following the Henderson-McKibbinTaylor rule, ${ }^{3}$ as set out in Henderson and McKibbin (1993) and Taylor (1993). In this model version, all central banks, with the exception of China's, target inflation and GDP growth. Compared to most central banks, the People's Bank of China has several policy targets, including price stability, economic growth, employment, balance of payments, financial markets reform and liberalisation (Zhou 2016). China's central bank targets inflation, GDP growth and the nominal exchange rate. In the first set of scenarios, the US and Chinese central banks automatically respond to macroeconomic outcomes according to the monetary rule. In the second set of scenarios, the Chinese central bank cuts short-term interest rates independently and subsequently responds to macroeconomic outcomes following the monetary rule. As for fiscal policy, government spending here is assumed to be exogenous and the government collects taxes to service its debt interests.

3 The nominal interest rate set by the central bank should respond to divergences of actual inflation from target inflation and of actual economic output from potential economic output. 
G-cubed features businesses that are forward looking in their investment and spending decisions, which are made based on current and past rates of return and future expected rates of return. Here, we expect businesses to invest less given expectations of lower returns in the future due to the imposition of tariffs. As such, it is an ideal tool with which to assess the potential impacts of these wideranging trade policies on the global economy.

Table 11.1 G-cubed model countries/regions in v.144

\begin{tabular}{|l|l|}
\hline United States & China \\
\hline Japan & India \\
\hline United Kingdom & Indonesia \\
\hline Germany & Other Asia \\
\hline Rest of euro area & Latin America \\
\hline Canada & Other emerging economies \\
\hline Australia & Eastern Europe and former Soviet Union \\
\hline South Korea & OPEC \\
\hline Rest of advanced economies & \\
\hline
\end{tabular}

OPEC $=$ Organization of the Petroleum Exporting Countries

\section{Literature review}

Over the past year, there has been increased attention on the potential adverse economic impacts of a trade war. The scope of these studies varies to a substantial degree and depends on the countries that are involved in the scenario analyses as well as the assumptions in general. A global trade war has far more negative repercussions, whereas a bilateral trade war leads to leakages to third countries. The upside to our analysis is that we have realistically focused on the two countries involved. In addition, we have included a suite of possible Chinese policy responses in a full-escalation scenario.

McKibbin and Stoeckel (2017) used the G-cubed model to simulate the effects of a range of multilateral trade war scenarios. They find that tariffs imposed by the United States on all imports from all countries would leave all countries and regions worse off. The United States itself is also worse off under this scenario, with GDP falling by 0.3 per cent in the first year, and the impact on China is three times larger, at -0.9 per cent. In a global trade war, all countries are worse off-some more than others due to their trade exposure. The losses to China, Germany and other countries in Asia are some three times larger than for the United States. 
Freund et al. (2018) from the World Bank used a computable general equilibrium model and considered three scenarios, all of which included mutual tariffs between the United States and China, with the third scenario including a decline in investor confidence. The authors find that third-party countries benefit from trade diversion when the two trading partners impose tariff surcharges. But, when investor confidence is shaken, these gains are more than offset for all regions by negative income effects. In this scenario, income losses range between 0.9 per cent for South Asia and 1.7 per cent for Europe and Central Asia. The biggest declines in incomes are recorded by China and the United States_up to 3.5 per cent and 1.6 per cent, respectively. The sectors most affected include agriculture, chemicals and transport equipment in the United States, and electronic equipment, machinery and other manufacturing in China.

Li et al. (2018) used a multicountry global general equilibrium model to simulate the effects of possible Sino-US trade wars, including both tariff and nontariff measures. The authors find that the United States can gain under unilateral sanctions measures on China, but it will lose if China takes retaliatory measures. Under a mutual trade war, China will lose more than the United States. Additionally, trade wars between China and the United States will hurt most countries and the world, especially in terms of GDP and manufacturing employment.

The trade war scenario analysis by the European Central Bank (ECB) is published as part of their economic bulletin dating from September 2018. By using the model of the International Monetary Fund (IMF) as well as their own global model, the ECB assesses both the trade and the confidence channels by which the economy might be impacted by the current trade war. The study examines a global trade war in which the United States imposes tariffs on all imports and all trading partners reciprocate these protectionist US measures. This explains the relatively higher impact on the US economy compared with China, as the latter can benefit from substitution effects. Furthermore, the study assumes that the trade tensions will ease going forward and will last for only two years.

\section{Simulations}

The first set of scenarios assesses the impact of three different outcomes of the trade dispute, excluding any Chinese policy response. The tariff shocks are assumed to be permanent. The second set considers the impact of three different Chinese policy responses in the event of a bilateral trade war. Table 11.3 summarises the key assumptions in each scenario.

The first set of scenarios is chosen to reflect the observed evolution of the trade dispute as well as a plausible intensification. Our first scenario, 'Symbolic retaliation', mirrors the first tit for tat between the United States and China in March 2018 after 
President Trump invoked Section 232 of the Trade Act (1962) and imposed tariffs of 25 per cent on steel and 10 per cent on aluminium imports. We find this scenario to have a largely neutral impact on long-term growth prospects. The second scenario, 'Escalated tensions', mirrors the tit for tat between the United States and China in July-August 2018, following the findings of the Section 301 investigation under the Trade Act (1974). The US Trade Representative then targeted US $\$ 50$ billion of imported Chinese products that were deemed instrumental in helping China achieve its goals of becoming a global leader in the advanced technology sector, prompting China to retaliate like for like. In September 2018, the United States imposed a further 10 per cent tariff on an additional US\$200 billion of Chinese imports, with China responding with 5-10 per cent tariffs on an additional US $\$ 60$ billion of US imports. Prior to the truce achieved at the G20 meeting in December 2018, a further escalation of the dispute was a distinct possibility. As such, we assume the worst-case scenario of a bilateral trade war in our third scenario, 'Trade war'.

The trade shocks in the simulations are designed to be close to the announced policies but will not capture the precise measures. With this caveat in mind, we compare the impact of each simulation against a baseline before the United States and China openly engaged in tit for tat. Given the six-sector setting in the G-cubed model, we convert the industry-specific tariffs to an aggregate rate that can be applied to the entire sector, based on the industry's share in that sector. We use 2016 bilateral import data from the World Integrated Trade Solution Trade Stats database to estimate the industry shares. We then apply the industry weights to the new tariffs and arrive at a sector-wide tariff rate.

A more detailed description of the three scenarios is as follows.

\section{Symbolic retaliation}

In March 2018, US metals importers faced higher duties following the imposition of tariffs on steel and aluminium ( 25 per cent and 10 per cent, respectively) sourced from several countries. China retaliated by raising duties (ranging from 15 per cent to 25 per cent) on its imports of US food, animal products and metal articles. In this simulation, we apply a sector-wide average tariff on US imports of Chinese durable manufacturing goods to reflect the higher levies on the metals industry. We also apply a sector-wide average tariff on Chinese imports of US nondurable manufacturing, agricultural, fishing and hunting and durable manufacturing goods to reflect higher levies on the affected industries.

\section{Escalated tensions}

In July 2018, the US administration imposed 25 per cent tariffs on US\$50 billion of Chinese goods, covering industrial, transport and medical products. China retaliated with 25 per cent tariffs on US\$50 billion of US goods, including soybeans, automobiles and aircraft. In this simulation, the sector-wide incremental tariff 
rate on US imports of Chinese durable manufacturing goods is revised to include new levies on machinery and equipment, transportation and other miscellaneous manufactured articles. For China, the sector-wide tariffs on US agricultural, fishing and hunting, durable manufacturing and nondurable manufacturing goods are also updated to reflect the new levies on agricultural products, transport equipment and chemicals and plastics.

\section{Trade war}

In a fully fledged trade war, the United States and China are assumed to raise tariffs on all bilateral imports. In this simulation, we apply 25 per cent tariffs on all sectors.

In 2018, China rolled out several supportive measures in response to not only a weaker external outlook arising from trade tensions, but also the slowing domestic economy (Table 11.2). In the second set of scenarios, we assess the efficacy of a package of Chinese policy responses in the event of a trade war against the same pre-dispute baseline. In the first scenario, 'Drip irrigation', the policy shocks are designed to be similar to the announced stimulus but will not fully capture the precise measures. In the second scenario, 'Pump priming', we assume the Chinese authorities provide much more aggressive policy support to shore up short-term growth. In the third scenario, 'Sell-off', we hypothesise that China counters US aggression through other nontariff means-namely, through a sell-off of its substantial holdings of US Treasuries.

Table 11.2 Chinese policy package in 2018

\begin{tabular}{|l|l|}
\hline Date announced & Policy measures \\
\hline March 2018 & $\begin{array}{l}\text { China announced import tariff cuts focused on consumer goods- } \\
\text { e.g. automobiles, pharmaceuticals. }\end{array}$ \\
\hline May 2018 & $\begin{array}{l}\text { A value-added tax cut (1 per cent) applied to manufacturing, transport } \\
\text { and construction firms. }\end{array}$ \\
\hline April, June, October 2018 & $\begin{array}{l}\text { The central bank cumulatively lowered commercial banks' required } \\
\text { reserve ratio from 17 per cent to 14.5 per cent. The interbank offered } \\
\text { rate was lowered by approximately 25 basis points since Q2 2018, } \\
\text { partly as a result of a round of required-rate-of-return cuts, as well as } \\
\text { proactive market operations by the People's Bank of China through } \\
\text { its mid-term lending facility and reverse repurchase. }\end{array}$ \\
\hline October 2018 & $\begin{array}{l}\text { Individual tax threshold raised to RMB5,000 from RMB3,500, as well as } \\
\text { policies on income tax deductions. Effective from January 2019. }\end{array}$ \\
\hline November 2018 & $\begin{array}{l}\text { Chinese authorities increased export tax rebates on about 400, mainly } \\
\text { capital, goods. }\end{array}$ \\
\hline
\end{tabular}

Source: MoFCOM, BHP analysis. 


\section{Drip irrigation}

This simulation captures major policies implemented in 2018 to stabilise the economy. Between March and October, the Chinese authorities lowered the required reserve ratio on three occasions (in April, July and October). Although the People's Bank of China did not engage in an outright reduction in the policy rate, the interbank offer rate-or what we would interpret as the shadow ratefell by 25 basis points over the same period in response to the liquidity injection. Accordingly, we reduce the short-term interest rate to reflect monetary easing. We also lower the personal income tax rate at the margin to reflect the increase in the tax-free personal income band. We also use a tax credit to proxy the package of tax rebates, tariff cuts and sales tax reductions offered to firms in durable and nondurable manufacturing.

\section{Pump priming}

In this simulation, the tax shocks are unchanged from the first simulation; however, monetary policy easing is assumed to be more aggressive (in our case, the cut to short-term interest rates is doubled). Government spending is also increased to reflect higher future expenditures on indigenous research and development to meet the authorities' long-term strategic objectives.

\section{Sell-off}

In this simulation, the tax and monetary policy shocks are unchanged from the first simulation. In addition, we assume that Chinese authorities withdraw their capital from the US Government bond market and redeploy this capital in domestic investment and other parts of the world. Presently, China's holdings of US Treasuries (worth US\$1 trillion) is equivalent to about 5 per cent of US nominal GDP. The shock is set up such that the United States will face a capital outflow equivalent to 5 per cent of GDP over the next 20 years-that is, a loss of 0.25 per cent of GDP per year. This $\$ 1$ trillion from the United States is then reallocated to the rest of the world in proportion to GDP. 
11. Modelling the economic impact of the Sino-US trade dispute

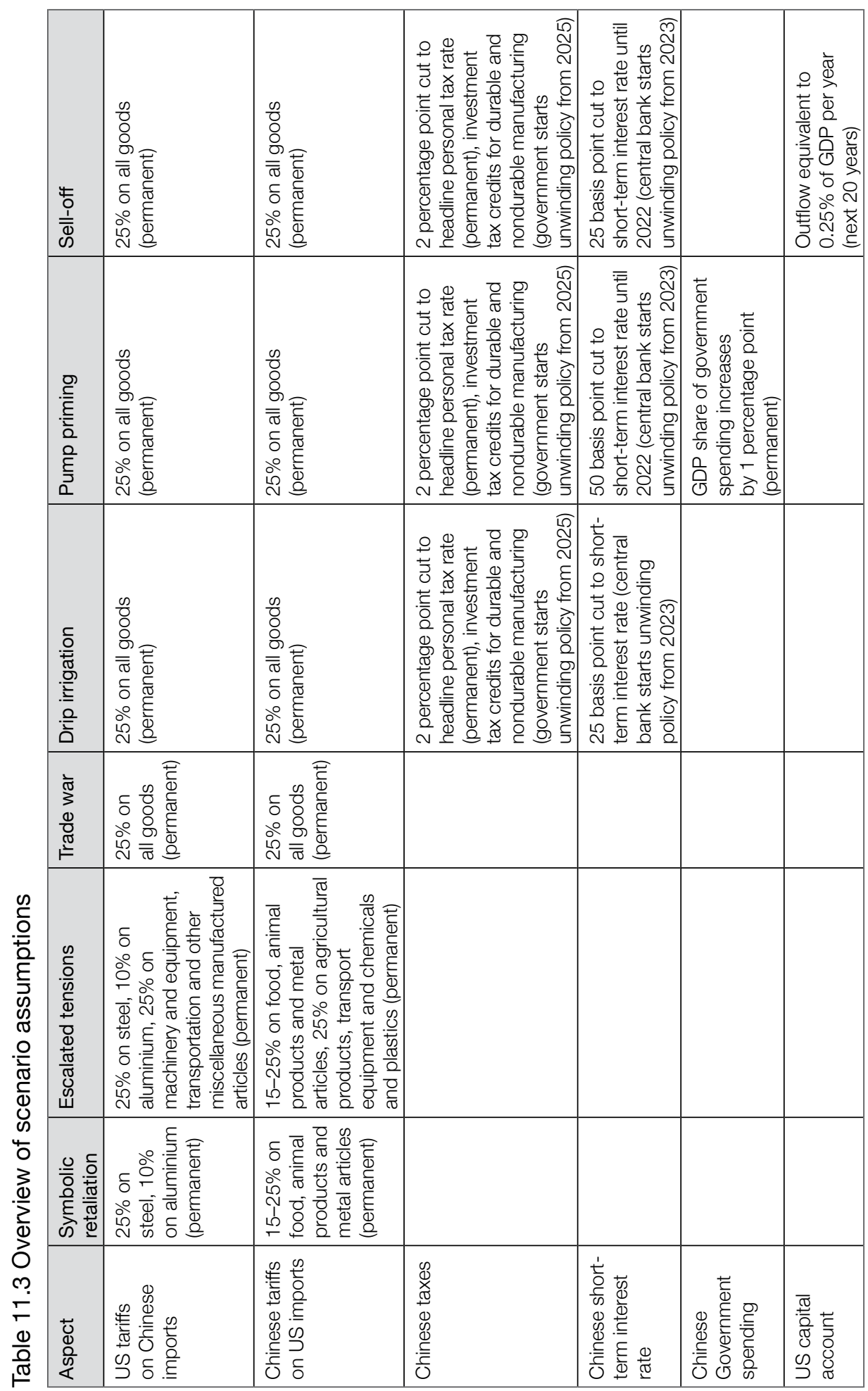




\section{Model results: Scenario set 1}

In the first set of simulations, we assess the impact of three different trade outcomes relative to a benchmark before the trade dispute. In the most benign of the three simulations, 'Symbolic retaliation', GDP deviates only slightly from the baseline (Figure 11.3, Exhibits 5-1). In the 'Escalated tensions' simulation, US and Chinese GDP fall by 0.2 per cent and 0.3 per cent, respectively, over the next decade. In the worst-case scenario, 'Trade war', both US and Chinese GDP decline by 0.5 per cent on average over the next 10 years. The initial impact on China is greater than that on the United States across all scenarios due to China's higher trade exposure. However, the cost to the United States becomes larger over time. On the other hand, third countries such as Germany and Japan will benefit from rising exports as activity is diverted away from the combatants. This is a positive for GDP in these countries (Figure 11.3, Exhibit 2) and, to some extent, this cushions the overall negative impact on the global economy.

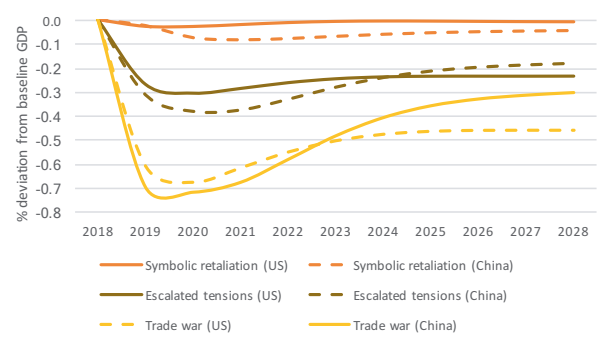

Exhibit 1 Impact on GDP from three simulated shocks

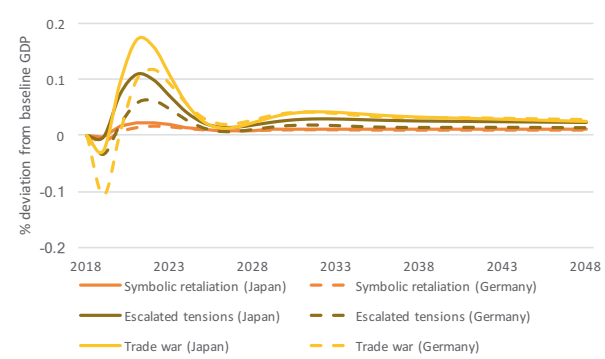

Exhibit 2 Impact on GDP

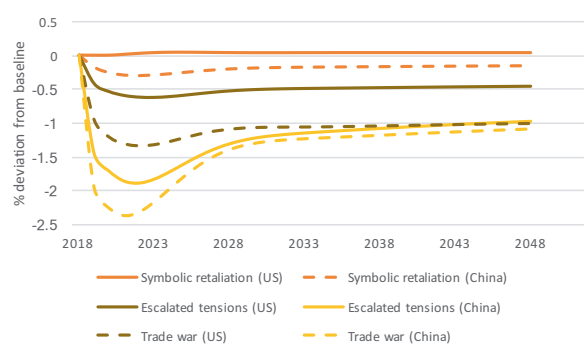

Exhibit 3 Impact on durable manufacturing output

Figure 11.3 Impact of trade tensions

Source: BHP analysis based on G-cubed model.

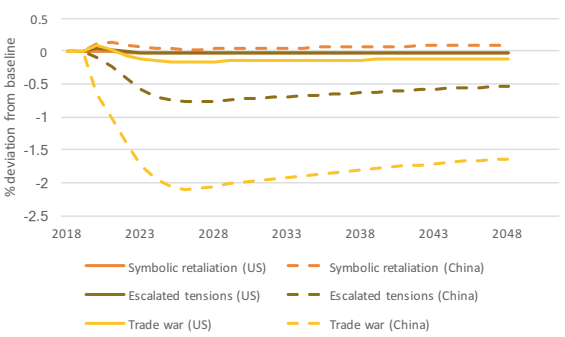

Exhibit 4 Impact on average wage

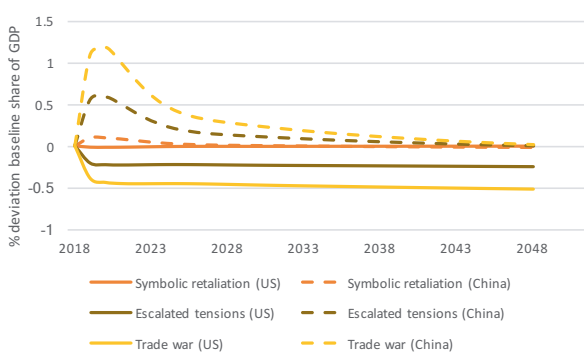

Exhibit 5 Impact on trade balance

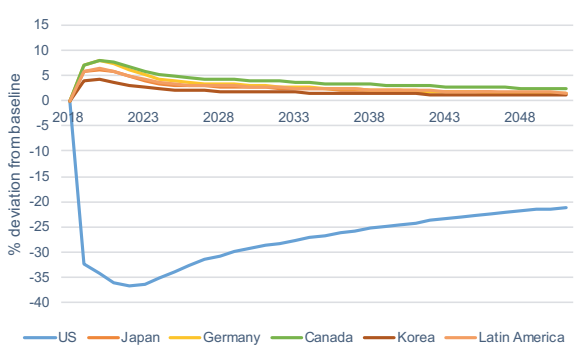

Exhibit 6 Imports of Chinese durable manufacturing goods from key trading partners 
Sectors facing protectionism will lose out, with durable manufacturing taking the biggest hit. This is a key sector targeted explicitly by both governments and accounts for the bulk of bilateral imports. The impact on China's durable manufacturing will also be much larger relative to the United States, due to the sector's bigger relative trade exposure (Figure 11.3, Exhibit 3). Tariffs increase the price of imported capital goods and lower firm profits and rates of return on investment. While an increase in tariffs may encourage a switch from foreign to domestic goods, the higher operating costs and lower returns on investment actually outweigh the benefits of an extra boost to domestic demand. As a result, investment and output fall in the United States and China, with a greater impact on China. The short to medium-term impact is greater on China but the difference narrows over time.

In the 'Trade war' scenario, wages could be -0.1 per cent and -1.5 per cent lower on average in the United States and China, respectively, over the next decade (Figure 11.3, Exhibit 4). The durable manufacturing sectors that are most impacted by the trade barriers will see the sharpest fall in employment. Businesses are expected to lower their demand for labour and wages will be driven down as they start to downsize operations. The slowdown in real activity dampens the effects of higher imported inflation. The United States and China are expected to see mildly higher inflation.

In China, the decline in return on capital discourages new investment and leads to an internal rebalancing in overall savings and investments. The sharp drop in investment could stem from reduced demand for imported raw materials and equipment. This change in the savings-investment balance leads to an improvement in China's trade position (Figure 11.3, Exhibit 5). The renminbi is also expected to weaken in the medium term as China experiences a sharper capital outflow given a reduced domestic need for investment. The weaker renminbi in turn increases the competitiveness of Chinese exports and encourages demand from other trading partners, such as Germany and Japan, mitigating some of the overall decline in exports (Figure 11.3, Exhibit 6). In contrast, the US trade position deteriorates, reflecting a slight worsening of its savings-investment balance. The United States experiences a drop in investment demand and a bigger drop in domestic savings. The change in relative rates of return between the United States and China attracts some capital inflow into the United States, which supports a stronger US dollar through the medium term. The stronger dollar encourages more consumption and domestic savings falls, leading to a weaker trade position. The strength of the US dollar also reduces the export competitiveness of US goods and services. While we mainly discuss the changes to nominal exchange rates, the change to real exchange rates largely follows a similar profile given the limited inflationary impact. 


\section{Model results: Scenario set 2}

In the second set of scenarios, we assess the effectiveness of a range of Chinese policy responses in the event of a trade war. In all three scenarios, the policy stimulus buffers a negative trade shock and leads to a smaller decline in China's medium-term output (Figure 11.4, Exhibit 1). Monetary easing lowers borrowing costs for domestic firms. Tax credits to the export-oriented manufacturing sector also increase aftertax profits and rates of return on investment, making it more attractive to expand business operations in these sectors. The change in relative return on investment also results in some capital being drawn away from the United States. Indeed, in all three scenarios, the United States experiences a steeper decline in investment, but the outcomes are not materially different from those absent a policy response.
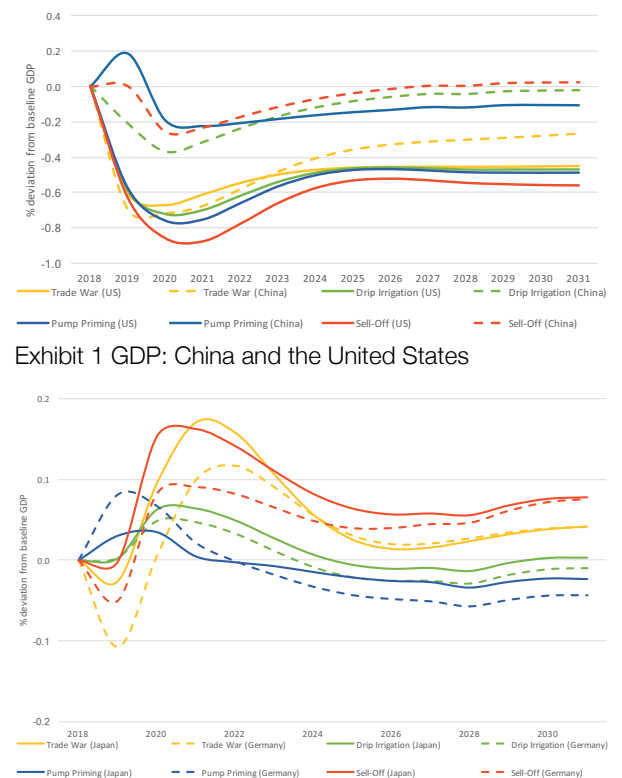

Exhibit 2 GDP: Japan and Germany

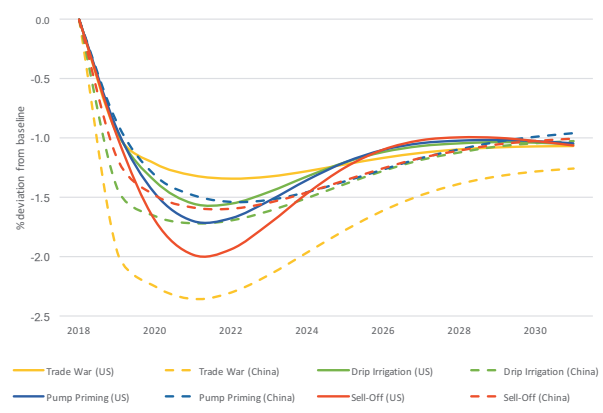

Exhibit 3 Durable manufacturing output: China and the United States

Figure 11.4 Impact of Chinese policies Source: BHP analysis based on G-cubed model.

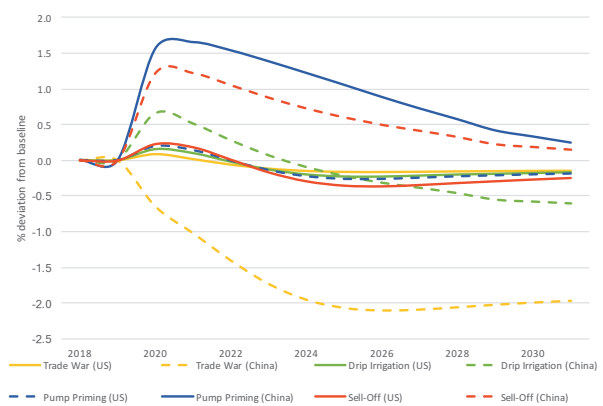

Exhibit 4 Average wage: China and the United States

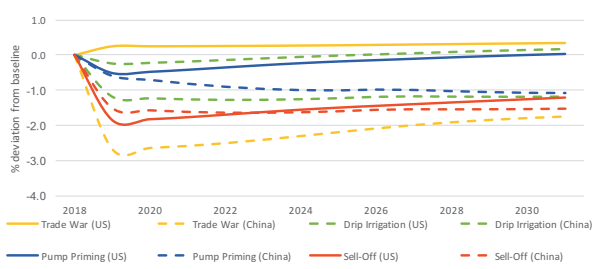

Exhibit 5 Nominal exchange rate: China and the United States

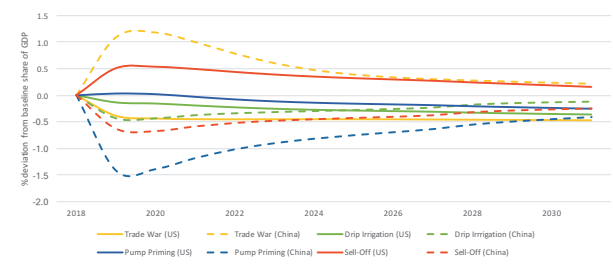

Exhibit 6 Trade balance: China and the United States 
China's choice of policies also leads to differentiated outcomes in the short and medium terms. A stronger stimulus under 'Pump priming' lends the greatest support in the short term, but this comes at the expense of lower output in the longer term as higher government spending necessitates some form of fiscal consolidation in the future. While the 'Sell-off' scenario is slightly less effective at offsetting the near-term shocks, the Chinese economy benefits from increased domestic investment from a redeployment of Chinese capital (away from US Treasuries) and sees a stronger pickup in real activity over the longer term.

From China's perspective, the 'Sell-off' scenario is expected to be as effective as 'Pump priming' in cushioning the impact of a bilateral trade war over the next decade, with GDP expected to be 0.1 per cent lower on average over the next 10 years in both cases. This compares with an average decline in China's GDP over the next decade by 0.5 per cent in a trade war and 0.2 per cent under the 'Drip irrigation' scenario. Over the next 10 years, US GDP is expected to decline by 0.5 per cent in a trade war and will worsen marginally with 'Drip irrigation' and 'Pump priming'. Under the 'Sell-off' scenario, US GDP is expected to fall by 0.7 per cent. These outcomes show that such retaliatory measures can be quite limited in their capacity to inflict economic damage on the United States. The limited economic damage and the politically explosive nature of a sell-off appear to support the views of some Chinese policymakers. ${ }^{4}$

Bystander countries such as Germany and Japan continue to benefit as trade activity and capital flows are diverted away from the combatants (Figure 11.4, Exhibit 2). However, ongoing EU-US trade talks have yet to make decisive progress and the threat of US auto tariffs remains tangible. If auto tariffs were to materialise, the boost to auto exporters from diverted trade is likely to fall significantly, with Japan experiencing a greater loss (compared with Germany) given its larger relative exposure to US final demand. In 2017, the United States imported US $\$ 40$ billion worth of Japanese-made cars and US $\$ 20$ billion worth of German-made cars.

Figure 11.4, Exhibit 3 shows that countercyclical measures can mitigate some of the negative impacts on investment from a trade war. Specifically, the stimulus increases the after-tax return from investing in China and reduces the relative attractiveness of investing in the United States. The more expansionary the policy ('Pump priming' being the most aggressive), the better the investment outcome for China is. For the United States, the pullback in investment is the largest under the 'Sell-off' scenario. For decades, foreign purchases of US Government securities have subsidised the borrowing costs of the US Government, relative to what it would have had to pay if it only had access to US domestic savings. This has also driven down the borrowing costs of US corporations in domestic markets. Under the 'Sell-off scenario, the

4 Chinese ambassador Cui Tankai compared selling US Treasuries to playing with fire and thought the authorities in Beijing would not wish to cause any financial instability in global markets (Lee 2018). 
outflow of capital leads to a drop in the US dollar and a rise in long-term US bond yields and borrowing costs; these two mutually reinforcing forces are expected to weigh on investment sentiment.

The stimulus also cushions the impact on Chinese employment from a trade war (Figure 11.4, Exhibit 4). Chinese businesses are expected to lower their demand for labour as operations are downsized. The slowdown in activity is moderated, leading to a milder decline in Chinese wages. Under a highly expansionary stance ('Pump priming'), wages could even rise as stronger government spending and investment activity bid up labour demand. In the United States, 'Sell-off' places the largest cap on US wage growth prospects in the medium term. These wage dynamics are expected to mirror investment decisions.

While the stimulus is in itself inflationary, economic activity generally remains below potential in all three scenarios, so China experiences only mildly higher inflation. The size of the stimulus under the 'Pump priming' scenario imparts the strongest inflationary impulse in the early years. In the United States, 'Sell-off has the largest impact on inflation. Specifically, the combined effect of lower demand for US Treasuries and a redirection of these capital flows towards other competitors leads to a depreciation in the US dollar relative to its major trading partners and the United States experiences higher imported inflation.

The stimulus raises the relative rate of return of investing in China and attracts capital inflows, so even with outright monetary easing, the renminbi falls by less in all three scenarios (Figure 11.4, Exhibit 5). In 'Sell-off, recipients of Chinese capital see their exchange rates appreciate so this to some extent dampens the strength of the renminbi against its non-US trading partners. However, the renminbi strengthens relative to the US dollar. On a trade-weighted basis, the renminbi depreciates the least in 'Pump priming', under which overall demand for Chinese capital is the highest. Across the three scenarios, capital flight out of the United States in 'Sell-off' leads to the weakest outcome for the US dollar.

The first set of scenarios showed that the drop in investment demand in China rebalances domestic savings and investment and leads to an improvement in China's trade balance (Figure 11.4, Exhibit 6). With a policy stimulus and higher investment needs, however, the improvement in China's trade balance will be reduced. In the case of 'Pump priming', the trade balance actually deteriorates as higher investment demand spurs capital inflows, which strengthen the renminbi. The stronger renminbi is expected to weaken the export competitiveness of Chinese goods and services. In 'Sell-off', demand for investment falls and capital flows out of the United States. Reduced support for the US dollar increases the export competitiveness of US goods and services and, taken together with lower demand for imports, moves the US trade position closer to balance. 


\section{Conclusion}

A trade war is costly for both the United States and China. While the United States will impose a larger cost on China in the initial years, it will suffer a similar medium-term adverse impact on growth. While both countries have a strong incentive to avoid a trade war because of the economic consequences, there may be circumstances in which policymakers are willing to accept some economic pain to try to change the behaviour of the other party in the pursuit of long-term strategic interests.

From China's perspective, while aggressive fiscal expansion appears to be an attractive policy option in the near term, by offering the most short-term relief, output in the longer term will be compromised. Further, a sharp increase in credit is inconsistent with China's strategic focus on deleveraging. While a diversification of Chinese foreign assets through a redeployment of its US holdings appears to be an attractive strategy prima facie, given it does not compromise the government's balance sheet or long-term prospects, the risks of further escalation makes it a strategy that one would not recommend. The Chinese Government, while occasionally adopting strong rhetoric, has consistently said it is committed to not escalating tensions, so such a provocative move appears relatively unlikely. However, it is wrong to say that China's options for retaliation are solely related to matching tariffs should it be pushed into a very tight corner. All up, we think the current policy approach by the Chinese Government is a sensible and conservative option that cushions the economy adequately in the near to medium terms, while reducing the chances of international repercussions.

\section{References}

American Chamber of Commerce in Shanghai (2017), Market Access Challenges in China, October 2017, Shanghai: AmCham.

David, J.E. (2019), Trump says he will delay additional China tariffs originally scheduled to start on March 1, CNBC, 24 February.

Erken, H., Giesbergen B. and Vreede, I. (2018), Re-assessing the US-China trade war, Rabobank, 26 November.

European Central Bank (ECB) (2018), Macroeconomic implications of increasing protectionism, ECB Economic Bulletin, June, Frankfurt am Main: ECB.

European Chamber of Commerce (2018), China: Certain measures on the transfer of technology-Request for consultations by the European Union, June, Brussels: DirectorateGeneral Trade, European Commission. 
Freund, C., Ferrantino, M.J., Maliszewska, M. and Ruta, M. (2018), Impacts on global trade and income of current trade disputes, MTI Practice Note No. 2, Washington, DC: World Bank Group.

Hass, R. and Balin, Z. (2019), US-China relations in the age of artificial intelligence, Artificial Intelligence and Emerging Technologies Initiative Report, 10 January, Washington, DC: The Brookings Institution.

Henderson, D.W. and McKibbin, W.J. (1993), A comparison of some basic monetary policy regimes for open economies: Implications of different degrees of instrument adjustment and wage persistence, International Finance Discussion Papers 458, Washington, DC: Board of Governors of the Federal Reserve System. doi.org/10.1016/0167-2231(93)90011-K.

International Monetary Fund (IMF) (2018), World Economic Outlook: Challenges to steady growth, January, Washington, DC: IMF.

Joint Committee on Taxation (2017), Macroeconomic analysis of the Conference Agreement for H.R.1, the 'Tax Cuts and Jobs Act', 22 December, JCX-69-17, Washington, DC: US Congress.

Lee, J. (2018), Exclusive: China not seriously considering U.S. Treasuries as trade war weapon-envoy, Reuters, 28 November.

Li, C., He, C. and Lin, C. (2018), Economic impacts of the possible China-US trade war, Emerging Markets Finance and Trade 54(7): 1557-77. doi.org/10.1080/154049 6X.2018.1446131.

McKay, H. (2019), BHP's Economic and Commodity Outlook, Melbourne: BHP, available from: www.bhp.com/media-and-insights/prospects/2019/02/bhps-economicand-commodity-outlook.

McKibbin, W.J. (2018), How countries could respond to President Trump's trade war, Australian Financial Review, 5 March.

McKibbin, W.J. and Stoeckel, A. (2017), Some global effects of President Trump's economic program, Centre for Applied Macroeconomic Analysis Working Paper 53/2017, Canberra: The Australian National University. doi.org/10.2139/ssrn.3028388.

McKibbin, W.J. and Wilcoxen P. (2013), A global approach to energy and the environment: The G-cubed model, in P.B. Dixon and D.W. Jorgenson (eds), Handbook of Computable General Equilibrium Modeling SET. Volumes $1 A$ and $1 B$, Amsterdam: North Holland. doi.org/10.1016/B978-0-444-59568-3.00015-8.

McKibbin, W.J. and Wilcoxen, P.J. (1999), The theoretical and empirical structure of the G-cubed model, Economic Modelling 16(1)(January): 123-48. doi.org/10.1016/S02649993(98)00035-2.

Meltzer, J.P. (2019), Developing a mutually beneficial US-China economic relationship, Up Front, 28 February, Washington, DC: The Brookings Institution. 
Meltzer, J.P. and Shenai, N. (2019), The US-China economic relationship: A comprehensive approach, Report, 28 February, Washington, DC: The Brookings Institution. doi.org/ $10.2139 /$ ssrn.3357900.

Politi, J. (2018), Trump's 'poison pill' in China trade fight, Financial Times, 9 October.

Sink, J. and Talev, M. (2019), Trump signs spending bill and declares emergency to build wall, Bloomberg, 15 February.

State Council Information Office of the People's Republic of China (2018), The facts and China's position on China-US trade friction, 24 September, Beijing.

State Council of the People's Republic of China (2015), Notice on printing and distributing 'Made in China 2025', 8 May, Beijing.

Taylor, J.B. (1993), Discretion versus policy rules in practice, Carnegie-Rochester Conference Series on Public Policy 39, Amsterdam: North Holland. doi.org/10.1016/01672231(93)90009-L.

United States Trade Representative (2019), 2018 Report to Congress on China's WTO Compliance, February, Washington, DC: Office of the United States Trade Representative.

Zhou, X. (2016), Managing Multi-Objective Monetary Policy: From the Perspective of Transitioning Chinese Economy. The 2016 Michel Camdessus Central Banking Lecture, International Monetary Fund, Washington, DC, 24 June. 
This text is taken from The Chinese Economic Transformation: Views from Young Economists, edited by Ligang Song, Yixiao Zhou and Luke Hurst, published 2019 by ANU Press, The Australian National University, Canberra, Australia.

doi.org/10.22459/CET.2019.11 